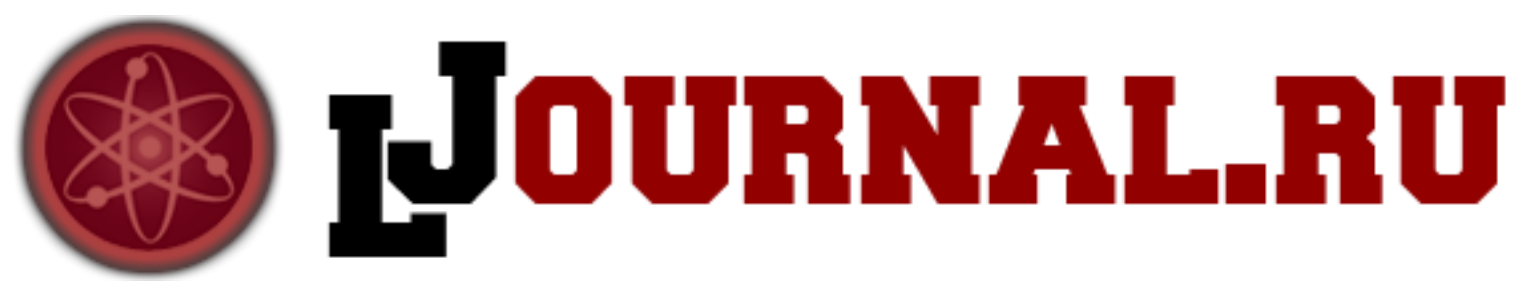

Волкова Т.А., Ларькова М.Ю.

ФГБОУ ВПО «Сибирский государственный индустриальный университет» Новокузнецк, Россия

doi: 10.18411/1j2016-1-03

\title{
О причинах приостановления или прекращения действия сертификатов соответствия на системы менеджмента качества в российских организациях
}

Во всём мире сертификация систем менеджмента качества (СМК), функционирующих в организациях различных отраслей промышленности и сфер экономики, стала элементом культуры производственно-хозяйственной деятельности и одним из серьёзных факторов конкурентоспособности на рынке. Сертификация показывает другим участникам рынка, что СМК данной организации разработана и организована с учетом определенных требований и эффективно функционирует, что обеспечивает высокое и стабильное качество продукции и услуг данной организации $[1,2]$.

Сертификация является в России и в мире одним из основных видов деятельности по оценке соответствия. Согласно Федеральному закону РФ от 27.12.2002 № 184-Ф3 «О техническом регулировании» под «сертификацией» понимается форма осуществляемого органом по сертификации (OC) подтверждения соответствия объектов требованиям технических регламентов, положениям стандартов, сводов правил или условиям договоров. Этот же термин в международном стандарте ISO/IEC 17000 формулируется как подтверждение соответствия третьей стороной, относящееся к продукции, процессам, системам или персоналу. Таким образом, сертификацию СМК 
следует рассматривать, как независимую оценку и подтверждение соответствия СМК организации требованиям международного или национального стандарта ISO 9001.

Следует отметить, что стандарт ISO 9001 не является обязательным и степень использования его организацией той или иной страны во многом зависит от объемов внешнеэкономических связей. Однако его стараются использовать всё чаще и получать сертификат для повышения конкурентоспособности организации на рынке. Согласно данным отчетов Центрального секретариата Международной организации по стандартизации по системам менеджмента, a также комментариям к отчетам В.Я. Белобрагина, в мире наблюдается устойчивое расширение масштабов применения стандарта ISO 9001 на СMK. На рисунке 1 представлена динамика роста количества сертификатов на СМК за пять лет.

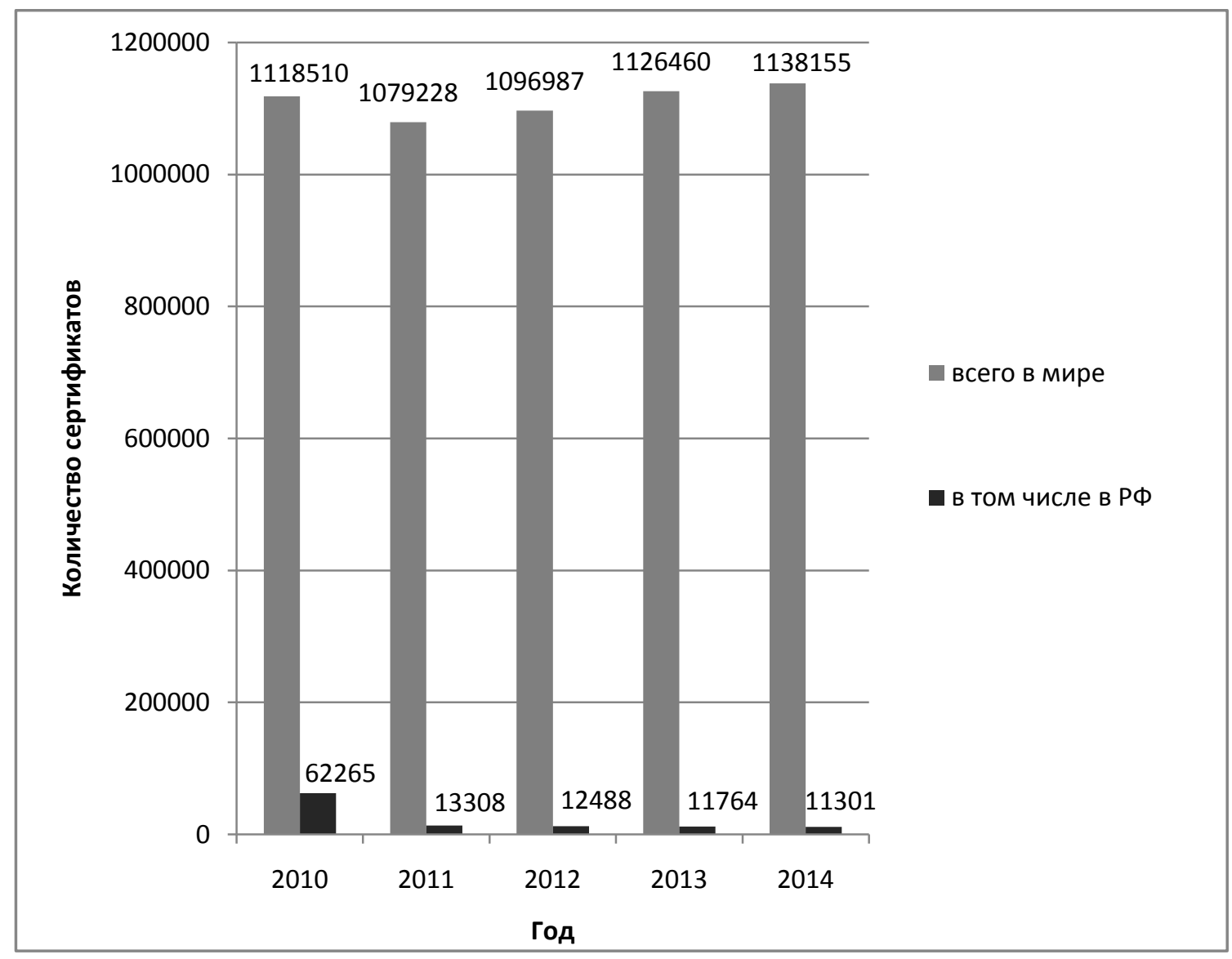

Рисунок 1 - Количество выданных в мире сертификатов на СМК 
Как видно из рисунка 1 в России сертификация СМК также развивается, что свидетельствует о высоком доверии к стандарту ISO 9001 у организаций, совершенствующих свои системы управления. Однако необходимо отметить, что выданный ОС сертификат на СМК сроком на три года не является гарантией того, что организация сохранит статус «держателя сертификата» на протяжении всего срока его действия. Согласно национальному стандарту ГОСТ Р 55568 (п. 9.3) существует несколько оснований для приостановления или прекращения действия сертификата на СМК.

Приостановление действия сертификата может осуществляться как по инициативе держателя сертификата при соответствующем запросе в ОС, так и со стороны ОС. В частности, ОС приостанавливает действие сертификата в тех случаях, если при инспекционном контроле (ИК) выясняется, что держатель сертификата не может выполнить требования, предъявляемые при сертификации, а также, если держатель сертификата отказывается от проведения ИК или его оплаты, не позволяет проводить ИК с требуемой периодичностью или не выполнил запланированные корректирующие действия по устранению несоответствий по результатам предыдущего ИК. Приостанавливается действие сертификата и в случае, если ОС выявляет нарушения правил использования сертификата и применения знака соответствия.

Отмена действия сертификата осуществляется ОС в случаях, если держатель сертификата не устранил причины, вызвавшие приостановление действия сертификата, или по его запросу в связи с изменением наименования или адреса, в связи с ликвидацией или прекращением производства продукции, на которую распространяется сертификат. Расширение или сужение области сертификации держателя сертификата также сопровождается выдачей нового сертификата, включающего в себя описание расширенной или суженной области сертификации, при этом предыдущий сертификат отменяется. Отмененный сертификат подлежит возврату в ОС. 
Практика работы ОС показывает (рисунок 2), что в большинстве случаев отмена действия сертификата на СМК происходит по инициативе заказчика услуг по сертификации СМК в связи с расширением или сужением области сертификации (35 \%), изменением наименования или адреса держателя сертификата (27 \%), прекращением производства продукции, на которую распространяется сертификат (18\%). При этом решение об оформлении нового сертификата в этих случаях принимается преимущественно во время планового ИК или на основании представленных держателем сертификата документов. Прекращение действия сертификата на СМК со стороны ОС осуществляется, если держатель сертификата не устранил причины, вызвавшие приостановление действия сертификата (20\%).

Среди наиболее часто встречаемых оснований приостановления действия сертификата на СМК, а впоследствии и его аннулирования, являются не выполнение держателем сертификата требований, предъявляемые при сертификации СМК (40 \%) или запланированных корректирующих действий по устранению несоответствий по результатам предыдущего ИК (24 \%), отказ от проведения ИК по причине сложного финансового положения организации (24 \%). Необходимо также отметить, что 12 \% организаций добровольно делают запрос о приостановлении действия сертификата на СМК.

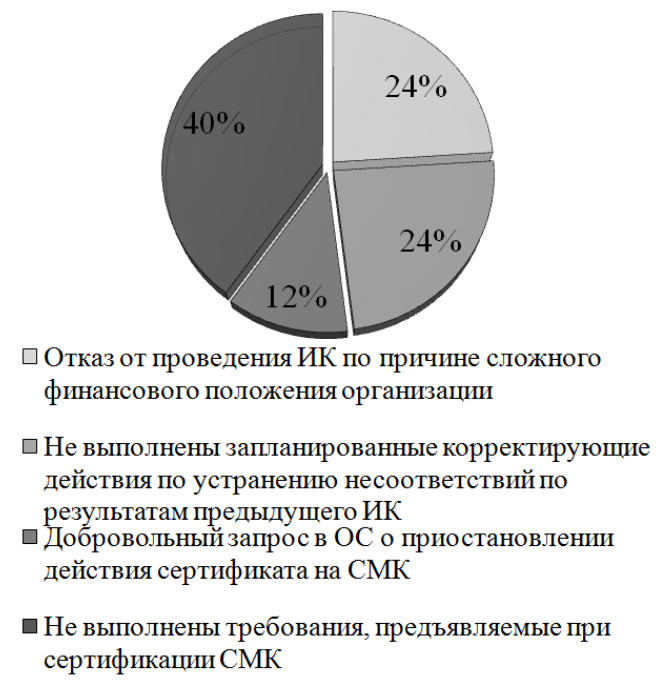

a)

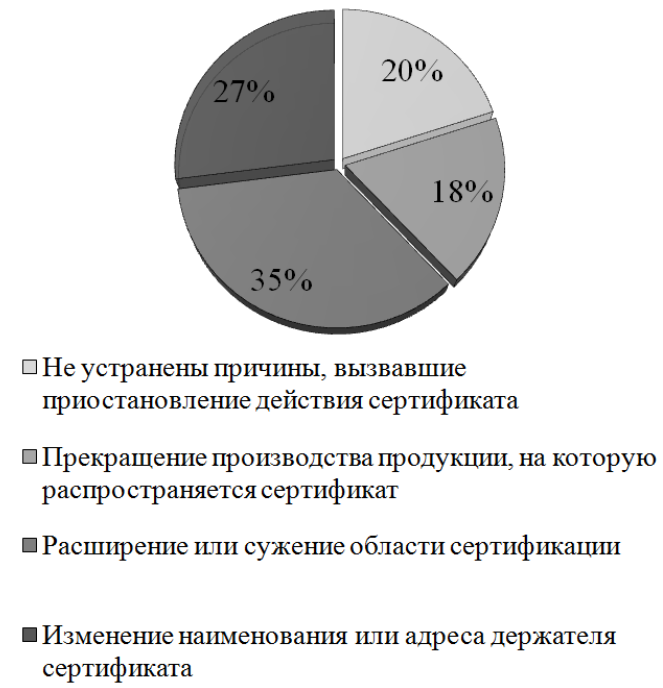

б) 
а) - причины приостановления сертификатов на СМК;

б) - причины отмены сертификатов на СМК

Рисунок 2 - Основные причины приостановления или прекращения действия сертификатов на СМК в российских организациях

Сертификат соответствия - это показатель стабильности и надежности организации. Информируя партнеров и клиентов о получении сертификата, высшее руководство организации сообщает об оптимизации процессов, улучшении работы персонала и повышении качества продукции. Эта информация, будучи грамотно поданной, однозначно будет способствовать расширению положительной публичной известности организации [3, 4]. В связи с этим очень важно, чтобы организация сохранила статус «держателя сертификата» на протяжении всего срока его действия.

\section{Литература:}

1. Волкова, Т.А. Формирование процессной модели системы менеджмента органа по сертификации систем менеджмента / Т.А. Волкова // Управление экономическими системами: электронный научный журнал. - 2014. - № 1 (61).

URL:

http://www.uecs.ru/index.php?option=comflexicontent $\&$ view=items\&id=2735.

2. Волкова Т.А. Обеспечение беспристрастности процесса сертификации систем менеджмента / Т.А. Волкова // Сертификация. - 2015. - № 3. - С. 33 37.

3. Волкова Т.А. Сайт органа по сертификации как инструмент для обеспечения информирования общественности о деятельности в области оценки соответствия / Т.А. Волкова // Экономика и управление : анализ тенденций и перспектив развития : сборник материалов II Международной науч.-практ. конференции : в 2-х частях. Часть $1 /$ Под общ. ред. С. С. Чернова. - Новосибирск : Издательство НГТУ, 2012. - С. 190 - 193. 
4. Попрыжко Л.А. Информирование общественности о деятельности органа по сертификации систем менеджмента качества на основе сайта в информационно-телекоммуникационной сети «интернет» / Л.А. Попрыжко, T. А. Волкова // Современные научно-практические достижения : сб. материалов междунар. науч.-практ. конф. (5-6 мая 2015 года) ; ЗападноСибирский науч. центр; Кузбасский гос. техн. ун-т им. Т.Ф. Горбачева. Кемерово, 2015. - С. $121-129$. 